http://kitaibelia.unideb.hu/

ISSN 2064-4507 (Online) • ISSN 1219-9672 (Print)

(C) Department of Botany, University of Debrecen, Hungary

22 (2): 304-316.; 2017

DOI: $10.17542 /$ kit.22.304

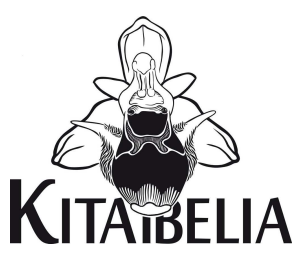

\title{
A Gagea minima (L.) Ker Gawl. és a Dictamnus albus L. újrafelfedezése a Dél-Tiszántúlon, valamint további florisztikai adatok az Alföldről
}

\author{
KORDA Márton ${ }^{1 *}$, ScHMIDT Dávid ${ }^{1}$, VIDÉKI Róbert ${ }^{2}$, HASZONITS Győző ${ }^{1}$, TiBORCZ Viktor ${ }^{1}$, \\ CsISZÁr Ágnes ${ }^{1}$, ZAGYvaI Gergely ${ }^{1}$, BARTHA Dénes ${ }^{1}$
}

(1) Soproni Egyetem, Erdőmérnöki Kar, Növénytani és Természetvédelmi Intézet, H-9400 Sopron, Bajcsy-Zsilinszky u. 4.; *korda.marton@gmail.com

(2) Doronicum Kft., H-9794 Felsőcsatár, Petőfi Sándor u. 13.

\section{Rediscovery of Gagea minima (L.) Ker Gawl. and Dictamnus albus L. in the Southern Tiszántúl and other floristic data from the Great Plain of Hungary (Alföld)}

\begin{abstract}
In this study we report relevant occurrence data of 49 species and hybrids and their habitats from the Great Plain registered in the period between 2011 and 2017. Due to importance for nature conservation, we present additional data of further 13 species. Most of the data are originated from riverine oak-elm-ash forests of South East Hungary (from the region of Gyula, Békéscsaba, Doboz settlements). The most important result of our study is the rediscovery of Gagea minima and Dictamnus albus. Besides, we report new occurrence data for the Great Plain (Alföld), as well as for the flora of the microregions in questions (e.g. Draba muralis, Nicandra physalodes, Cystopteris fragilis) and also present the data of the regionally endangered species (e.g. Inula helenium, Ophioglossum vulgatum). Some rare weed taxa (e.g. Calepina irregularis, Cardamine impatiens), spreading adventive taxa (e.g. Chorispora tenella, Euphorbia maculata, Phytolacca americana, Ph. esculenta, Sicyos angulata) and in surveys rather underrepresented species (e.g. Loranthus europaeus, Arabis hirsuta, Rumex confertus) are reported too.
\end{abstract}

Keywords: Alföld, South-Tiszántúl, floristical data, Gagea minima, Dictamnus albus

Összefoglalás - A szerzők a 2011 és 2017 közötti időszakban az Alföldről gyűjtött florisztikai adataik közül az érdekesebbeket adják közre. A cikkben 49 faj, illetve hibridfaj előfordulását, élőhelyi körülményeit, esetenként a térségből ismert történetét mutatjuk be. További 13 faj esetében - azok természetvédelmi jelentősége miatt - a Magyarország edényes növényfajainak elterjedési atlaszához (BARTHA et al. 2015, a továbbiakban: „Flóraatlasz”) megjegyzések nélküli kiegészítéseket is közlünk. A tárgyalt adatok többsége a Gyula, Békéscsaba és Doboz térségében elterülő keményfás ligeterdőkből származik, emellett további szórványadatokat közlünk az Alföld számos pontjáról. Eredményeink közül legjelentősebbek a Dél-Tiszántúlról kipusztultnak vélt Dictamnus albus, illetve az „elfeledett” Gagea minima újrafelfedezése. Emellett több, az Alföld, illetve az adott közép- vagy kistáj flórájára új (például Draba muralis, Nicandra physalodes, Cystopteris fragilis), illetve regionálisan veszélyeztetett faj adatát (például Inula helenium, Ophioglossum vulgatum) ismertetjük. Bemutatunk továbbá ritka gyomnövényeket (például Calepina irregularis, Cardamine impatiens), terjedőben lévő adventív fajokat (Chorispora tenella, Euphorbia maculata, Phytolacca americana, Ph. esculenta, Sicyos angulata), illetve az adott térségben feltűnően alultérképezett fajokat (pl.: Loranthus europaeus, Arabis hirsuta, Rumex confertus).

Kulcsszavak: Alföld, Dél-Tiszántúl, florisztikai adatok, Gagea minima, Dictamnus albus 


\section{Anyag és módszer}

Cikkünkben a 2011 és 2017 közötti időszakban az Alföld különböző részterületein végzett terepi kutatásaink során gyűjtött florisztikai adatok közül adjuk közre az érdekesebbeket. Adataink túlnyomó része a Fekete- és a Fehér-Körös menti erdőkből és tágabb környezetükből (Berettyó-Körös-vidék, illetve Körös-Maros köze) származik.

Fentiek mellett szórványosan közlünk adatokat a Nyírségből, a Közép-Tisza-vidékről, a Duna-Tisza közi síkvidékről (Kecskemét környéke), a Hajdúságból, a Duna-menti síkságról (Szentendrei-sziget déli fele), valamint a Dráva menti síkságról. Felsorolt adataink közül néhány közöletlen (ineditum) adatként került be a Flóraatlaszba (BARTHA et al. 2015), amelyeket jelentőségük hangsúlyozása és az előfordulási viszonyok részletezése miatt cikkünkben szövegesen jellemzünk. ${ }^{1}$ Szerepeltetünk adatokat olyan fajokról is, amelyek egy adott tájegységben nem újak, de jelentőségük miatt fontosnak tartottuk az előfordulás megerősítését.

Adatainkat DöVÉNYI (2010) kistájkatasztere alapján, középtáj szinten soroltuk be és adtuk meg. A középtájak esetében alkalmazott rövidítések:

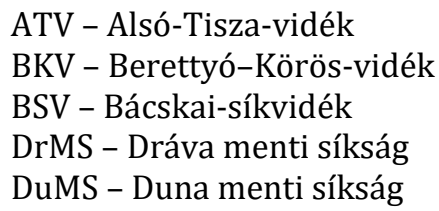

$$
\begin{aligned}
& \text { DTK - Duna-Tisza közi síkvidék } \\
& \text { H - Hajdúság } \\
& \text { KMK - Körös-Maros köze } \\
& \text { KTV - Közép-Tisza-vidék } \\
& \text { Ny - Nyírség }
\end{aligned}
$$

Az előfordulási körülmények bemutatását követően megadjuk a közép-európai flóratérképezési rendszer kvadrátazonosítóját (NIKLFELD 1971), majd a megtalálás évszámát.

Az adatközlők esetében alkalmazott rövidítések: BD - Bartha Dénes, CsÁ - Csiszár Ágnes, HGy - Haszonits Győző, KÉ - Kergyik Éva, KM - Korda Márton, MF - Major Ferenc, ND - Naár Dénes, SD - Schmidt Dávid, TV - Tiborcz Viktor, VR - Vidéki Róbert, VD - Vojnic-Zelic Dániel.

A közölt taxonok KIRÁLY (2009a) munkájának sorrendjét és sorszámait követik.

\section{Enumeráció}

\section{Pteridophyta - Harasztok}

\section{Equisetum hyemale L. - Téli zsurló}

BKV: Álmosd: Daru-láp, magasabb fekvésű, főként pionír fafajok alkotta erdőfoltban, nagyobb polikormonok. [8597.2; VR \& KM; 2016]. - Az Alföld Dunától keletre eső részén ritka, BARTHA et al. (2015) mindössze 6 kvadrátból jelzi.

17. Ophioglossum vulgatum L. - Kígyónyelv

BKV: Doboz: Sebes-foki-erdő, idősebb, 76 éves feketediósban, kb. 180 tő [9293.1; KM; 2017]. - A Dél-Tiszántúlon ritka, SALLAINÉ KAPOCSI et al. (2012) szerint kipusztulással veszélyeztetett faj, melynek a legjelentősebb állományai a Doboz és Gyula környéki keményfás tömbökben élnek, ahonnan már BöLÖNI et al. (2000) és JAKAB (2012b) is jelzi, de a Sebes-

\footnotetext{
${ }^{1}$ Itt szeretnénk felhívni a figyelmet arra, hogy a Flóraatlaszban megjelenő egyes adatok terepi felmérői (szerzői) nem minden esetben azonosak az adott flóratérképezési egység kvadrát alapú terepi felmérőivel (lásd BARTHA et al. 2015: 15-28.). Ennek oka, hogy a kvadrát alapú felmérés adatain túl számos egyéb forrásból is kerültek adatok az Adatbázisba (vö. BARTHA l.c. 7-8.). Elsősorban ritkább, kisszámú előfordulással rendelkező taxonok adatainak hivatkozása esetén ezért javasoljuk a Flóratérképezési Adatbázis gazdájának (Soproni Egyetem, Erdőmérnöki Kar, Növénytani és Természetvédelmi Intézet) levélbeli megkeresését az idézendő adat szerzőjének vagy szerzőinek megadása érdekében.
} 
foki-erdőből eddig nem volt adata. Tapasztalataink szerint idős feketediósokban igen jelentôs állományai alakulhatnak ki.

43. Cystopteris fragilis (L.) Bernh. - Törékeny hólyagpáfrány

KMK: Öcsöd: 45 éves fehérnyáras a Körös mentén, néhány tő [9187.2; KM; 2017]. - Az állományban a Fraxinus pennsylvanica második szintet alkot, melyre a Vitis riparia felfutva összefüggő, teljes záródású liánszintet hoz létre, úgy, hogy alatta át lehet járni. Az előálló fényhiány miatt a gyepszint nudum, a nyílt, üde talajfelszínen tenyészik a páfrány. PINTÉR (2009) az Alföldről igen ritkaként említi, megjegyezve, hogy főleg kutakban fordul elő. Kútból jelzi BoRos (1930) is a Duna-Tisza közéről, illetve nyírségi erdőkből is, míg ZóLYomi (1945-1946) a Tiszaugari-erdőből, ahol egy keményfás ligeterdő termőhelyén létrehozott egzóták által uralt állomány gyepszintjében fordult elő. BARTHA et al. (2015) alföldi adatot nem közöl a fajra vonatkozóan.

\section{Dicotyledonopsida - Kétszikűek}

$104 \times 105$. Salix $\times$ multinervis Döll. (S. cinerea L. $\times$ S. aurita L.)

Ny: Baktalórántháza: Dégenfeld-kastély parkjában, több egyed egy foltban, spontán megjelenés [7998.3; BD; 2015]. - Egykor a Korhányi-erdő keleti szélén is előfordult több példány, melyek az 1970-es évekre ismeretlen okok miatt eltűntek. A hibrid alföldi előfordulásai meglehetősen ritkák.

$110 \times 111$. Juglans $\times$ intermedia Jacques (J. regia L. $\times$ J. nigra L.)

Ny: Baktalórántháza: Baktalórántházi-erdő ÉK-i szegélyén a nyírkércsi községhatár közelében futó árok mentén, három idős ültetett példány [7998.3; BD; 2015]. - Termőkorú példányok, magjaik csírázóképesek, elszaporításával az illetékes erdészet szakemberei próbálkoztak. A példányok származása ismeretlen.

155. Loranthus europaeus Jacq. - Fakín

BKV: Gyula: Mályvádi-erdő, Sitke, Város-erdő [9294.3, 9294.4, 9393.2, 9394.2; KM; 2016]; KMK: Békéscsaba: Pósteleki-erdő, Fácános, Gerla, [9293.3, 9393.1; KM; 2017]. - BARTHA et al. (2015) térképe szerint a Dél-Tiszántúlon kifejezetten ritka faj. Gyula, illetve Békéscsaba térségében mindössze egy kvadrátban jelöli előfordulását. Már Soó \& MátHé (1938) is jelzi, a fenti települések mellett Dobozról is. Terepbejárásaink alkalmával az említett települések határában elterülő keményfás ligeterdőkben, illetve a termőhelyükön kialakított kocsányostölgy-ültetvényekben jelentős állománya él. Alultérképezettsége minden bizonnyal nehezen észrevehető voltával magyarázható.

197. Rumex confertus Willd. - Tömött lórom

ATV: Csanytelek: Tisza-töltés [9386.4; SD; 2016], Baks: Tisza-töltés [9486.2; SD; 2016]. KTV: Vezseny: Tisza-töltés [8987.3; SD \& KM; 2013]. - Nedves rétek, üde kaszálók magas termetű lóromfaja. A Tisza árvízvédelmi töltésén a felsorolt települések határában helyenként gyakori. Kisszámú korábbi adatát SCHмOTZER (2015) fóként bükkaljai és közép-tiszavidéki előfordulásokkal jelentősen bővítette, ekképpen a Flóraatlaszban elterjedési centruma jól kirajzolódik. Ezen túlmenően a faj minden bizonnyal elterjedtebb, az Alsó- és Közép-Tisza-vidéken (továbbá a mellékfolyók mentén) megvannak a számára optimális élőhelyek. Térképezhetőségét nehezítő körülmény, hogy a fő élőhelyét jelentő töltésgyepeket rendszeresen kaszálják, így a növény nem virágzik. Jellegzetes, nagyméretű tőlevélrózsájáról, más lóromfajokkal szemben finoman szőrös leveléről azonban jól felismerhető ilyen állapotában is.

273. Phytolacca americana L. - Amerikai alkörmös

KMK: Békéscsaba: Hajlás, [9393.1; KM \& KÉ; 2017]. Fiatal fekete dióval elegyes cserfelújítás vágástéri gyomnövényzettel jellemezhető gyepszintjében szórványosan. - BALOGH 
\& JUHÁsZ (2012a) országszerte egyre gyakoribb felbukkanására hívja fel a figyelmet. BARTHA et al. (2015) térképe szerint a Dél-Tiszántúlon is jelentősen elterjedt faj, de Békéscsaba környékéről nem jelzi.

274. Phytolacca esculenta van Houtte - Kínai alkörmös

BKV: Doboz: Faluhelyi-erdő, [9293.4; KM \& VD; 2016]. 20 év körüli, teljes záródású cser főfafajú, jellegtelen erdőben. Az erdőrészlettel határos kertek felől terjed, néhol tömegesen. - BALOGH \& JUHÁSz (2012b) Magyarország számos településén tapasztalható elvadulását említi, nyugat-dunántúli súlyponttal, de hozzáteszi, hogy ez valószínűleg csak annak köszönhető, hogy célzott keresése leginkább ott volt jellemző. BARTHA et al. (2015) térképe alapján a faj a Dél-Tiszántúlon ritka, csak néhány kvadrátban fordul elő. Doboz környékéről nem jelzi.

348. Silene bupleuroides L. - Gór habszegfü

BKV: Báránd [8693.3; SD \& KM; 2012]. Csatornaparton a 42-es út mentén, néhány tő. - A Tiszántúlon igen ritka löszpusztai fajnak a legkeletibb aktuálisan ismert hazai előfordulása. BARTHA et al. (2015) további három tiszántúli kvadrátban jelöli, ezen kívül TóTH (2003) Mezőtúr, míg CSATHó (2009) Battonya és Mezőhegyes mellől ismerteti előfordulását.

471. Mahonia aquifolium (Pursh) Nutt. - Magyallevelű mahónia

KMK: Békéscsaba: Pósteleki-erdő, a Wenckheim-kastély környéki erdőrészletek cserjeszintjében szórványos, a kastély parkjából kivadulva [9393.1; KM \& KÉ; 2017]. - Települések környékén egyre gyakrabban találni elvadult egyedeit. BARTHA et al. (2015) térképe alapján a Dél-Tiszántúlon ritka.

518. Hesperis sylvestris Crantz - Erdei estike

BKV: Gyula: Gelvács, 3 tő [9394.3; KM; 2016]; Mályvádi-erdő, kb. 70 tő [9394.2; KM; 2016]. Gelvácson egy középkorú, jellegtelenedő keményfás ligeterdőben, míg a Mályvádi-erdőben egy 18 éves, teljes záródású kocsányos tölgy fiatalos szegélyében, a megelőző állomány hagyássávjában. - A környék erdeiből régóta ismert faj, a Gyula és Sarkad közötti erdőkből már BORBÁs (1881) is közli. MÁTHÉ (1936) Sarkadról és a Gerla-Marói-erdőből jelzi. KERTÉsz (1989) a dobozi Sebes-foki-erdőben és a Szanazugban találta. BöLÖNI et al. (2000) 1998ban már csak Gelvácson találta kisebb állományát. BARTHA et al. (2015) az Alföldről csak ezt a gelvácsi adatot jelzi.

522. Chorispora tenella (Pall.) DC. - Alacsony cikkesbecő

DTK: Kecskemét D [9184.1; SD, CsÁ, KM \& TV; 2016], Kecskemét K [9084.4; SD, CsÁ, KM \& TV; 2016], Nyárlőrinc [9185.1; SD, CsÁ, KM \& TV; 2016]. Mindenütt a 44-es út padkáján. Utak mentén helyenként terjeszkedőben lévő egyéves faj, amelynek kora tavasszal virágzó útszéli állományai a szirmok színe alapján könnyen észrevehetők. A Duna-Tisza közéről elsőként KIRÁLY \& KIRÁLY (2005) közlik egy vetésből, majd 2010-ben MESTERHÁZY Attila (in BARTHA et al. 2015) Izsák és Kiskunmajsa térségéből. Kecskemét melletti tömeges előfordulásáról Nagy Tímea és Takács Attila (in MolNÁR et al. 2017) számoltak be, ahol magunk is megfigyeltük. Adataink ezen előfordulásokat bővítik.

532. Cardamine impatiens L. - Virágrúgó kakukktorma

BKV: Gyula [9394.1; SD \& KM; 2016]. - Az Alföldön szórványos előfordulású faj (BARINA \& KIRÁLY 2009), a Nyírség kivételével csaknem az egész Alföldről hiányoznak az aktuális adatai (vö. BARTHA et al. 2015). A Gyulai-erdőtömbben nitrofil aljnövényzetű ültetett tölgyesek tavaszi aszpektusában nem ritka. Ilyen jellegü termőhelyeken az ország más területein is várható, terjedőben lévő faj. Elvirágzás után még sokáig megfigyelhető kórója alapján is jól felismerhető és térképezhető.

552. Arabis hirsuta (L.) Scop. s. str. - Borzas ikravirág

BKV: Gyula: a Fehér-Körös töltésgyepjében nem ritka [9394.3; SD, KM, TV \& MF; 2016]. - A Flóraatlaszban (BARTHA et al. 2015) mindössze három tiszántúli adata szerepel, amely je- 
lentős alultérképezettségre utal. Ehhez egyaránt hozzájárulhat a faj jelentéktelen külseje, korai és rövid virágzási ideje, valamint közepesen nehéz határozhatósága.

570. Draba muralis L. - Kövi daravirág

BKV: Gyula K [9394.3; SD, CsÁ, KM \& TV; 2016], Gyula ÉK [9394.1; SD, CsÁ, KM \& TV; 2016]. A Fehér-Körös töltésgyepjében. - Az Alföldről a közelmúltig nem jelzett faj megjelenését a Tisza gátján Takács Attila és Nagy Tímea (in PAPP et al. 2016: 186-187) publikálta. 2016 tavaszán hasonló körülmények között találtuk a növény számos egyedét kora tavaszi egyévesek társaságában a Fehér-Körös gátoldalán.

578. Neslia paniculata (L.) Desv. - Parlagi sömörje

BKV: Gyula: Mályvádi-erdő, erdőszegélyben 3 tő [9394.3; TV; 2016]. DTK: Abony: Zsombékos dűlőtől É-ra, a 40-es út menti gabonatáblák szegélyében, szórványos [8885.2; HGy; 2017]. - Az Alföldön igen szórványos előfordulást mutat, ezen belül a Tiszántúlról mindössze négy kvadrátban van ábrázolva (BARTHA et al. 2015). A főként gabonatáblák szélén, gyomos mezsgyéken alacsony egyedszámban felbukkanó faj az Észak- és NyugatDunántúlon jóval gyakoribbnak tűnik, ami a célzott gyomflorisztikai kutatásokkal is magyarázható.

622. Calepina irregularis (Asso) Thell. - Ráncos matyó

KTV: Tiszakürt [9186.1; SD, KM \& TV; 2016]; Cserkeszőlő [9186.2; SD, KM \& TV; 2016]; Kunszentmárton [9187.4, 9187.2; SD, KM \& TV; 2016]. Mindenütt a 44-es út mentén, többfelé nagy mennyiségben. KMK: Gyula DNy: Kétegyháza keleti határában az út mentén [9493.1; SD, KM \& TV; 2016]. - Zavart gyepekben, főként gátoldalakon találtuk, ahol virágzás idején látványos csoportjait könnyen észre lehet venni. Adataink a Közép-Tisza vidékéről BARTHA et al. (2015) térképén feltüntetett mindössze egyetlen előfordulást egészítik ki további öt újjal. A Dél-Tiszántúlon már jóval elterjedtebb.

717. Potentilla indica (Andrews) Focke - Díszeper

BKV: Szabadkígyós: kastélypark, meghonosodott [9392.4; SD, KM, TV \& MF 2016].

$827 \times 829$. Prunus $\times$ fruticans Weihe $(P$. spinosa $\mathrm{L} . \times$ P. domestica $\mathrm{L}$.)

BKV: Gyula: Mályvádi-erdő: erdőtömbben lévő vadföld szegélyében több, termőkorú példány [9294.3; BD \& KM; 2016]. - Nyúlánk megjelenésével, kevesebb elágazásával, kevesebb töviseivel, nagyobb leveleivel, hosszabb kocsányú virágával, nagyobb és kissé elliptikus termésével jól különbözik a kökénytől. Zavart termőhelyeken, főleg települések környékén egyre gyakrabban lehet vele találkozni. Békés megyében vadgazdálkodási célból is ültették/ültetik erdőszélekre.

1010. Geranium palustre E. Torner - Mocsári gólyaorr

BKV: Álmosd: Daru-láp, kiszáradt füzlápban és nem zsombékoló magassásosban, nagyobb foltokat alkot [8597.2, 8597.4; VR \& KM; 2016]. - Az Alföldön kifejezetten ritka faj, Soó (1966, 1980) csak nyírségi előfordulását említi. BARTHA et al. (2015) emellett egy bodrogközi kvadrátból is közli.

1042. Euphorbia maculata L. - Foltos kutyatej

KTV: Szolnok: Városközpont, Kossuth tér, Verseghy park, Zagyva menti kerékpárút, térkövezés között [8887.1; HGy; 2017]. DrMS: Harkány: kemping [0175.1; SD; 2016]. DuMS: Mohács: révkikötő [0078.1; SD; 2016]. - Települési környezetben napjainkban már országosan sem számít ritkának, adatai az utóbbi években tovább szaporodtak. Díszkövezett nyílt felületek (pl.: vasútállomások peronja, bevásárlóközpontok parkolói, városi terek, járdaszegélyek) mellett felbukkan utak mellett, zavart homoki gyepekben is.

1067. Euphorbia taurinensis All. - Görög kutyatej

H: Kaba, a város belterületén néhány tő [8693.1; SD \& KM; 2012]. - Délkelet-európai eredetű, hazánkban adventív faj. Az Alföld területén korábban csak a Duna mellékéről és Monor környékéről jelezték (Soó 1966, BARTHA et al. 2015). Adatunk a faj első tiszántúli előfordulása. 
1070. Dictamnus albus L. - Nagyezerjófú

KMK: Kétegyháza, Békéscsaba-Lőkösháza vasútvonal mentén, 1 tő [9593.1; VR; 2016]. - A vasútvonal szakasz környezeti hatásvizsgálati dokumentációjához végzett terepi felmérés során, a vasúti pálya mellett (közel a Kétegyháza és Elek közötti közigazgatási határhoz) 2016. április 14-én, Amorpha fruticosa zárt cserjésében került elő egyetlen! hatalmas tő. A növény május 26-i újbóli felkeresésekor bőségesen virágzott. A behurcolás valószínűsége csekély. Ezt a megállapítást erősíti a környezetében, illetve a vasúti pálya mentén található számos erdőssztyeppfaj megléte. A pályát kísérő jellegtelen cserjés sávban megmaradt kisebb degradált löszgyepfoltokon jobb és bal oldalt is több helyen a védett Aster sedifolius több száz töves állománya található. A fejlesztéssel nem érintett jobb oldalon még további védett fajok élnek, mint a Peucedanum officinale, az Anchusa barrelieri és az Inula germanica, továbbá említést érdemel még a nem védett Pseudolysimachion orchideum. A Dictamnus albus ugyancsak ezen az oldalon él, így a beruházás közvetlenül nem érinti, de a faj védelme megkívánja a körültekintő kivitelezést. Az élőhelyét a másik irányból egy szántó határolja, melynek helyrajzi szám szerinti határától 2 m-re (a jelenleg tényleges határától 5 m-re) fordul elő a tő, így az elszántással, mint potenciális veszélyeztető tényezővel is számolni kell.

A faj a Dél-Tiszántúlon a kipusztult növényfajok között volt számon tartva (SALLAINÉ KAPOCSI et al. 2012). A Dél-Tiszántúlon mindig is igen ritka volt, irodalmi források előfordulását mindössze három helyről jelzik. KoREN (1883) Kondorosról és a Szarvashoz tartozó Nagy-Csákóról - ez utóbbi adat jelenik meg BoRBÁs (1881) flóraművében Szarvas lelőhelylyel, melyet Koren levélben közölt vele -, míg HALÁSz (1889) Makó környékéről. Ez utóbbi esetében érdemes felhívni a figyelmet arra, hogy Halász Árpád a fajt egyértelműen a kertekben ültetett fajok között, apró betúkel tárgyalja. Ennek ellenére a későbbi botanikai szakirodalomba a makói adat őshonos előfordulásként ment át. A később megjelenő flóraművek rendre e fenti két adatot ismétlik (Soó \& MáTHÉ 1938, Soó \& JÁvorKA 1951, Soó 1966 stb.). A Körös-Maros Nemzeti Park Igazgatóság működési területére új védett növényfaj.

1083. Acer tataricum L. - Tatár juhar

Ny: Vásárosnamény: a Nyíregyházára vezető vasút mellett, egykor feltöltődött mederben található degradált erdőfolt szélén több példány [7899.4; BD; 2016]. - A környéken, a Nyírség ÉK-i részén ma is több előfordulása ismert (BARTHA et al. 2015).

1175. Elatine alsinastrum L. - Pocsolyalátonya

BKV: Gyula: Mályvádi-erdő, vízállásos nyiladékokon nem ritka, kb. 500 tő [9294.3, 9394.1; KM; 2016]. - Gyula közvetlen környékéről csak egy aktuális adata ismert (DeLI 2012, BARTHA et al. 2015). A jelentős állomány minden bizonnyal a felmérés során tapasztalt csapadékos időjárásnak köszönhető.

1190. Sicyos angulata L. - Szögletes gyepütök

ATV: Lakitelek: a Tisza árterén a 44-es út hídjánál [9186.1; SD \& KM; 2013]. BKV: Békés: a Körös árterében, puhafás ligeterdőben, néhány tő [9192.4; KM \& KÉ; 2017]. - A hasonló élőhelyigényű és növekedési formájú földitökökkel (elsősorban a levél alakjában is hasonló Bryonia dioica-val) termés nélküli állapotban viszonylag könnyü összetéveszthetősége miatt a Flóraatlasz térképén valószínúleg alulreprezentált faj. Élőhelyén gyakran további adventív liántermészetű fajok, az Echinocystis lobata és a Vitis riparia is tömegesen fordul elő, így fent közölt termőhelyein is. Előfordulásai a Tisza és mellékfolyóinak árteréhez kötődnek, kevés aktuális adatát VIRóK et al. (2010), TAKÁCS et al. (2014) és Schmotzer \& Táborská (in BARTHA et al. 2015) ismerteti.

1217. Chamaenerion angustifolium (L.) Scop. - Erdei deréce

BKV: Gyula: Mályvádi-erdő nyugati szegélyénél, a vésztározó vízbeeresztő műtárgya előtti nagyméretű zúzott kővel felszórt területen 1 tő [9294.3; KM \& KÉ; 2017]. - KIRÁLY (2009b) szerint az Alföldön igen ritka faj, mely BARTHA et al. (2015) térképe alapján az Alföld közép- 
ső és déli területein nem fordul elő. A Flóraatlasz megjelenése óta, TAKÁcs et al (2016) is jelzi a Dél-Tiszántúlról, Szentesen a Kurca partjáról. Dél-Tiszántúlon előkerült egyed pionír megtelepedés, hosszabb távú fennmaradása kétséges.

1320. Tordylium maximum L. - Borzas szarvasgyökér

BKV: Bagamér: a település délkeleti határában, az országhatár közvetlen közelében, löszmélyút mezsgyéjén, néhány tő [8598.3; SD \& KM; 2012]. - Az Alföldön ritka (Soó 1970), az Érmellékről nem volt adata. Legközelebb a Dél-Tiszántúl néhány távolabbi lelőhelyéről közli KERTÉSz (2000) és JAKAB (2005).

1329. Orlaya grandiflora (L.) Hoffm. - Laputurbolya

BSV: Nagybaracska: Bátmonostor felé vezető út mellett, gyomos szegélynövényzetben, néhány tő [9979.2; SD \& TV; 2014]. - A térségből mindössze három adatát ismertük. Bajától északra az Illancs területén Boros Ádám (1958) és Moesz Gusztáv (1912) gyűjtötte (SzUJKóLACZA \& KovÁTs 1993), újabban Barina Zoltán (in BARTHA et al. 2015) Nemesnádudvar mellett találta.

1391. Nymphoides peltata (S.G. Gmel.) Kuntze - Tündérfátyol

DuMS: Szeremle: a Sugovicában állományképző [9879.3; SD; 2016]. - A hazai Alsó-Duna árterén nem számít ritkának, de a Sugovicából eddig nem jelezték.

1449. Myosotis sparsiflora J.G. Mikan - Lazavirágú nefelejcs

BKV: Doboz: Sebes-foki-erdő, keményfás ligeterdőkben, és a termőhelyén kialakított különböző ültetvényekben [9293.1, KM; 2017]. - Érdekes módon BARTHA et al. (2015) nem jelzi a környéken. Legközelebb JАКАВ (2005) nyomán Geszt mellől ábrázolja, annak ellenére, hogy a Gyula, Doboz és Békéscsaba környéki keményfaligetekből régóta ismert. MÁTHÉ (1936) a Gerla-Marói-erdőből közli, míg KeRTÉsz (1989) e mellett a Sebes-foki-erdőben is látta. BöLÖNI et al. (1998) felmérése a Fekete- és Fehér-Körös menti keményfaligetek minden jelentősebb tömbjéből kimutatta.

1503. Galeobdolon argentatum Smejkal - Ezüstös sárgaárvacsalán

BKV: Doboz: Faluhelyi-erdő [9293.4; KM, CsÁ, ND \& SD; 2016]. - Húsz év körüli, teljes záródású cser főfafajú, jellegtelen erdőben. Az erdőrészlettel határos kertek felől terjed, néhol tömegesen. BöLöNı et al. (2000) feltételezik, hogy Gyulán a Város-erdőben ezt a taxont találták.

1566. Nicandra physalodes (L.) Gaertn. - Szilkesark

BKV: Álmosd: kukoricavetés gyomos szegélyében 10-20 tő [8597.2; VR \& KM; 2016]. - Hazánkban ritkán, időszakosan felbukkanó ritka gyomnövény, hazája Peru. Mindössze két aktuális előfordulása ismert, mindkettő dunántúli (SCHMIDT \& LENGYEL 2008, PINKE et al. 2016). Az Alföldről eddig nem közölték.

1600. Verbascum pulverulentum Vill. - Pamutos ökörfarkkóró

DrMS: Gordisa [0275.1; SD; 2016], Tésenfa D [0274.2; SD; 2016], Kémes [0174.4; SD; 2016], Cún-Majláthpuszta [0274.1; SD; 2016], Piskó D [0273.2; SD; 2016], Vajszló [0173.2; SD; 2016]. - Töltésgyepekben, útmenti mezofil szegélygyepekben a felsorolt lelőhelyein elég gyakori. A Dél-Dunántúlon szórványos előfordulású (KIRÁLY 2009c), konkrét adata azonban kevés van. A Dráva-síkról Ortmann-né Ajkai (in BARTHA et al. 2015) Drávaiványi és Felsőszentmárton határából jelzi. Fenti adataink ezen előfordulásokat bővítik ki kelet felé a közös magyar-horvát Dráva-szakasz mellékéről.

1691. Orobanche cernua L. in Loefl. - Bókoló vajvirág

BKV: Berettyóúffalu [8895.1; SD \& KM; 2012], Bakonszeg [8894.2; SD \& KM; 2012]. - Ürmöspuszta-töredékekben, számos egyed, Artemisia santonicum-on. A faj hazai megléte a közelmúltban BARINA et al. (2005) alapján nyert bizonyítást. A cikkben közölt elterjedési térképhez képest új adatokat csak (a Flóraatlaszban is szereplő) fenti két lelőhely jelent. 
1725. Galium rivale (Sibth. et SM.) Griseb. - Kapaszkodó galaj

BKV: Álmosd: Daru-láp, kiszáradt füzlápban, kékperjésben, magassásosban, ritka, de szálanként jellegtelen gyepben is. [8597.2; VR \& KM; 2016]. - Jellemzően lápi élőhelyekhez kötődő ritka faj. BARTHA et al. (2015) térképe mindössze egy kvadrátból jelzi az Alföldön.

1785. Dipsacus pilosus L. - Erdei fejvirág

BKV: Doboz: Papholt-erdő [9293.4; KM \& SD; 2016], Sebes-foki-erdő [9293.1; KM; 2017]; Gyula K: Mályvádi-erdő [9394.2; KM \& SD; 2016]. - A Dél-Tiszántúlon ritka, csak Gyula, Doboz, Sarkad és Békéscsaba keményfás ligeterdő-tömbjeiben fordul elő, jellemzően a keményfaligetekben, de a Papholt-erdőben idős feketediósban is él. A faj előfordulása ismert a környékről, BARTHA et al. (2015) is jelzi, de a fenti kvadrátok ehhez képest kiegészítést adnak.

1851. Inula helenium L. - Örménygyökér

BKV: Gyula: Mályvádtól D-re, Dukerék-dűlő, csatornában kb. 110 tő [9394.1; KM; 2016]. A viszonylag jelentős állomány egy - a megtalálás időpontjában - száraz csatorna szegélyében fordult elő, több tíz méter hosszan. A Dél-Tiszántúlon ritka, SALLAINÉ KAPOcSI et al. (2012) szerint kipusztulással veszélyeztetett faj. A legközelebbi adata a sarkadi Remeteerdőből származik, ahol 1988-ban egy virágzó tövét találták (KERTÉSz 1996), de a szerző 2000-ben már arról számol be, hogy többé nem került elő (KERTÉsz 2000). JAKAB (2012a) szerint innen kipusztult.

1875. Iva xanthiifolia Nutt. - Rézgyom

BKV: Nagyrábé: kukoricásban szórványosan [8793.4; SD \& KM; 2012]. H: Nádudvar: törmelékhalmon illetve trágyadepónia környezetében [9093.3; SD \& KM; 2012]. - Hazánkban összefüggő elterjedési gócponttal rendelkezik a Dél-Tiszántúlon (a Flóraatlasz térképén nagyjából a Lőkösháza-Orosháza-Nagylak háromszögben), ahol az 1950-es évektől fokozatosan terhes özöngyommá vált (HóDI 2012). Másutt csak szigetszerű előfordulásai ismertek, így az északról határos Közép-Tisza-vidéken már csak pontszerűen bukkan fel.

1885. Galinsoga ciliata (Raf.) S.F. Blake - Borzas gombvirág

KMK: Békéscsaba: Marói-erdő, akácosok közötti nyiladékon, néhány tő [9393.3; KM; 2017]. Egyre inkább terjedőben lévő faj, melyet a Dél-Tiszántúlról BARTHA et al. (2015) nem jelez.

2046. Mycelis muralis (L.) Dumort. - Kakicsvirág

BKV: Doboz: Madárfoki-erdő, keményfás ligeterdőben, néhány tő [9293.4; KM; 2016]. - A faj előfordulása ismert Békéscsaba és Gyula határában elterülő keményfás ligetek néhány pontjáról (BöLÖNI et al. 2000). A fenti adat ezt a sort bővíti. BARTHA et al. (2015) térképe szerint a faj igen ritka a Dél-Tiszántúlon.

\section{Monocotyledonopsida - Egyszikűek}

2163. Scilla vindobonensis Speta - Ligeti csillagvirág

KMK: Békéscsaba: Gerla DK-re nyúló részében, 66 éves, közepes természetességi állapotú keményfás ligeterdőben kb. 1800 tő [9393.1; KM; 2017]. - A Gyula, Doboz és Sarkad környéki keményfás ligeterdőkben, illetve a helyükön kialakított ültetvényekben való előfordulása közismert, számos szerző tárgyalta már (pl. MÁTHÉ 1936, BöLÖNI et al. 2000, SALLAINÉ KAPOCSI 2012a). Ezekben az erdőkben magunk is százezres nagyságrendű állományait találtuk. A Békéscsaba községhatárához tartozó erdőkből eddig nem jelezték előfordulását.

2178. Allium moschatum L. - Pézsmahagyma

DuMS: Szigetmonostor: Szigeti homokok, nyílt mészkedvelő homokpusztagyepek természetközeli részein helyenként gyakori [8380.2; SD, HGy \& TV; 2016]. - Az évelő nyílt homoki gyepek keleti elterjedésű „kiskunsági” szubasszociációjának (Festucetum vaginatae „da- 
nubiale") egyik jellegzetes faja, amely a társulás több más tagjával együtt (pl. Centaurea arenaria, Secale sylvestre, Tragopogon floccosus) jelenik meg a területen.

2224. Gagea minima (L.) Ker Gawl. - Apró tyúktaréj

BKV: Gyula: Mályvádi-erdő [9294.3; KM \& SD; 2016]. - Hazai lelőhelyeinek többsége a Dunazug-hegységben, elsősorban a Gerecse területéről ismertek, további szórványadatai a Középhegység más tájegységeiről vannak. Az Alföldről ezidáig recens adata csak a SajóHernád-síkról volt ismert (TAKÁCS et al. 2013). 2016. március 24-én váratlanul került elő a Gyula melletti Mályvádi-erdőből mintegy 50 töves állománya. Élőhelye egy 90 éves, kocsányos tölgy uralta, jó állapotú keményfás ligeterdő Fraxinus angustifolia subsp. danubialis, Ulmus laevis és Quercus cerris eleggyel. A gyepszintben többek között Ophioglossum vulgatum, Corydalis cava, Corydalis solida, Festuca gigantea, Pulmonaria officinalis, Viola sylvestris, Lamium maculatum, Scilla vindobonensis és Carex sylvatica is előfordul. A szóban forgó erdőrészlet a Mályvádi-erdő északi részén található, közvetlenül amellett az erdőrészlet mellett, ahonnan BöLöNI et al. (2000) az Asarum europaeum, a Melica uniflora és az Aegopodium podagraria előfordulását jelzi. A terepbejárások során, többszöri keresés ellenére is csak az Asarum europaeum és a Melica uniflora jelenlétét sikerült megerősíteni, az Aegopodium podagraria nem került elő. A Gagea minima területen való jelenléte jól illeszkedik a BölöNI et al. (2000) által közölt fajlistába, mely szerint a fentebb említett három faj, illetve az Allium ursinum és a Milium effusum bizonyítékai a Mályvádi-tömb Erdélyi-szigethegységgel való egykori kapcsolatának. Adatunk a faj egyetlen biztos adata a Dél-Tiszántúlról, egyben második előfordulása az Alföldön.

A G. minima tiszántúli előfordulása nem újkeletű, több irodalmi forrás is jelzi. SIMONKAI (1881) Berekböszörmény mellől említi a Sebes-Körös felsőbb vidékének flóráját tárgyaló cikkében. Megjegyzése, mely szerint „Erdốk televény talaján, Bereg-Böszörménynél, a Gagea Silvatica Pers társaságában", illetve a további fajok, melyeket ezzel a lelőhellyel említ (pl.: Dipsacus pilosus, Ulmus laevis), arra enged következtetni, hogy a Mályvádi-erdőhöz hasonló termőhelyen fordult elő a faj. Az érintett település közvetlenül az országhatár mellett fekszik, így nem zárható ki, hogy az adat jelenlegi határainkon kívülről származik, de a III. Katonai Felmérés térképe szerint az 1800-as évek utolsó évtizedeiben Berekböszörmény környékén két nagyobb erdőtömb is volt (Vén-erdő, Bereg-erdő). Ezek nagyobb része a mai Magyarország területére esik, így valószínűbb, hogy az adat a mai határainkon belülről származik. Ma ezek többségének helyét szántók foglalják el, az erdők kis foltokra zsugorodtak. Ugyancsak tiszántúli adatát közli HALÁsz (1889) Makó környékéről a Csanádi-erdőből, ez a terület azonban ma Romániához tartozik. Érdemes azonban megjegyezni, hogy Halász Árpád a flóralistájában külön jelölte „az Alföld ritkább vagy érdekesebb fajait”, mely jelölés a G. minima esetében nem szerepel. Soó \& MátHé (1938) e fenti két adatot idézi - később DRAGULEŞCu (1995) Soó \& MÁTHÉ (1938) munkájára hivatkozva jelzi előfordulását.

Ugyancsak egy Makó környéki adatra hívja fel a figyelmet PENKSZA \& KAPOCSI (1998), akik TóTH (1967) doktori értekezésének fajait is közlik florisztikai cikkükben. Tóth Mária a Maros menti növénytársulásokat vizsgálta, köztük a keményfás ligeterdőket. Ezekben a társulásokban kijelölt 13 kvadrátból háromban + értékkel szerepelt a Gagea minima (2 Makóhoz, 1 Klárafalvához tartozott). Az adat valószínűleg PENKSZA \& KAPOCSI (1998) előtt nem került publikálásra, így minden bizonnyal elsikkadt. Érdemes volna az érintett erdőkben célzottan keresni a növényt.

2227. Gagea villosa (M. Bieb.) Duby - Ugari tyúktaréj

BKV: Gyula: Mályvádi-erdő, útmenti gyomos szárazgyepben, néhány tő [9394.1; SD; 2016]. - A hazai tyúktaréjok között az egyetlen gyomjellegú növény, amely kedveli a homokoslöszös talajú zavart termőhelyeket, így gyakran látható városi parkokban, útszéleken, temetőkben, szőlők között. Kiterjedéséhez viszonyítva a Tiszántúlról alig van adata, BARTHA et al. (2015) mindössze 14 kvadrátban tünteti fel. 
2580. Cyperus difformis L. - Rizspalka

H: Hajdúnánás: a település északkeleti határában, az M3-as autópályához közel egy belvizes mélyedésben számos egyed [8194.2; SD \& KM; 2013]. - Hazai előfordulásainak túlnyomó része a Közép-Tisza-vidék és a Nagykunság belvizes szántóföldjein összpontosul (vö. MolnÁR \& PFEIFFER 1999), a Tisza-tótól északra csak egy bőcsi közléssel (VIRóK \& FARKAS 2007) és régóta megerősítetlen nyírségi adatokkal rendelkezett.

2676. Cephalanthera damasonium (Mill.) Druce - Fehér madársisak

BKV: Doboz: Sebes-foki-erdő, jellegtelen kocsányostölgy-ültetvényben, 14 tő [9293.1; KM; 2017]. - A Dél-Tiszántúlon csak igen szórványosan előforduló faj, melynek legjelentősebb állományai a Doboz, Gyula és Békéscsaba környéki keményfás tömbökben élnek (BARTHA et al. 2015, MolnÁR V. 2011a). Innen már BölÖNI et al. (2000) és SALLAINÉ KAPOCSI (2012b) is jelzi, de a Sebes-foki-erdőből eddig nem volt adata.

2687. Platanthera chlorantha (Custer) Rchb. in Mössler - Zöldes sarkvirág

BKV: Gyula: Sitka, 85 éves, jó állapotú keményfás ligeterdőben 3 tő [9294.3; KM; 2016], Mályvád-erdő, fiatal, teljes záródású kocsányos tölgy fiatalos 4 tő, keményfás ligeterdőben 4 tő [9394.1, 9394.2; KM; 2016]. - Doboz: Faluhelyi-erdő, feketediósban és közepes természetességű keményfás ligeterdőkben, összesen 8 tő [9293.4; 2016], Sebes-foki-erdő, jellegtelen keményfás ligeterdőben, illetve annak fekete dióval elegyes állományában, összesen 20 tő [9293.1; 2017].

A Platanthera bifolia és a Platanthera chlorantha előfordulásának története meglehetősen érdekesen alakul a Doboz, Békéscsaba, illetve Gyula környéki keményfás ligeterdőkben. Már MÁTHÉ (1936) jelzi előfordulását a Gerla-Marói-erdő és a Szanazug keményfás ligeteiből, és FARKAS (1999) is említi az előbbiből. Ezzel szemben BöLÖNI et al. (2000) a Platanthera bifolia tárgyalása kapcsán felhívja a figyelmet arra, hogy kutatásaik során a $P$. chlorantha nem került elő az említett erdőkből, szemben a meglepően nagy számban előforduló P. bifolia-val. Bár SALLAINÉ KAPOCSI et al. (2012) a P. chlorantha-t sebezhetőként szerepelteti a Dél-Tiszántúl növényfajainak vörös listáján, de MoLNÁR V. (2011b), illetve BARTHA et al. (2015) aktuális adatokat nem közöl a térségből, az ábrázolt pontok szerint a fajnak csak 1900 és 1989 közötti adatait sikerült feltárni. Ezzel szemben a térképek a $P$. bifolia jelentős aktuális előfordulásáról tanúskodnak. A 2016 és 2017 folyamán végzett terepbejárásaink alkalmával, mely során a Körösök menti keményfás ligeterdőket vizsgáltuk, mi a fentiekkel ellentétes megfigyeléseket tettünk. A felmérés során általunk talált 36 virágzó Platanthera-tő kivétel nélkül $P$. chlorantha-nak bizonyult. Mindemellett regisztráltunk 1109 tőleveles állapotú, tehát határozásra nem alkalmas Platanthera egyedet is, mely akár P. bifolia is lehet. A történethez érdekes adalék Soó (1929) orchidearevíziója, melyben Boros (1922) Békéscsaba és Doboz közti erdőkből származó $P$. bifolia adatát $P$. chloranthara helyesbíti, amelyre később Soó \& MÁTHÉ (1938) is visszautal.

\section{További kiegészítések Magyarország edényes növényfajainak elterjedési atlaszához}

Az alábbiakban néhány olyan védett faj adatát közöljük, melyeket BARTHA et al. (2015) térképei nem ábrázolnak. Az adatok kivétel nélkül az Álmosd és Kokad között elterülő Daru-lápról származnak (BKV). A terület a Hajdúsági Tájvédelmi Körzet része, így botanikai értékei alapvetően ismertek, ezért az alább felsorolt fajok részletes ismertetésétől eltekintünk, de természetvédelmi jelentőségük miatt, mint kiegészítő adatokat közzétesszük. Az adatok Vidéki Róbert és Korda Márton megfigyeléseiből származnak, 2016-ból. A terepbejárás csak a 8597.2 és 8597.4 kvadrátokat érintette. 
A 8597.2 és 8597.4 kvadrátokban egyaránt előfordulnak: Thelypteris palustris Scott, Dianthus superbus L., Pseudolysimachion longifolium (L.) Opiz, Cirsium rivulare (Jacq.) All., Cirsium brachycephalum Jur.

Csak a 8597.2 kvadrátban fordul elő: Gentiana pneumonanthe L., Iris sibirica L.

Csak a 8597.4 kvadrátban fordul elő: Dryopteris carthusiana (Vill.) H.P. Fuchs, Stellaria palustris Retz., Carex appropinquata Schumach., Epipactis tallosii A. Molnár et Robatsch, Neottia ovata Bluff. et Fingerh., Anacamptis palustris subsp. elegans (Jacq.) Bateman, Pridgeon et Chase.

\section{Köszönetnyilvánítás}

A szerzők köszönetet mondanak a terepi bejárásokon résztvevő kollégáknak: Kergyik Éva, Major Ferenc, Naár Dénes, Vojnic-Zelic Dániel. Köszönettel tartozunk a Körös-Maros Nemzeti Park Igazgatóságnak, hogy a körösközi erdők kutatását lehetővé tették, terepi munkánkat segítették. Külön köszönet illeti Forgách Balázst, aki mindig segítségünkre volt, illetve Sallainé Kapocsi Juditot, aki az irodalmi források felkutatásában nyújtott nélkülözhetetlen segítséget. A kézirat gondos lektorálását Csathó András Istvánnak köszönjük.

\section{Irodalom}

BALOGH L. \& JUHÁSz M. (2012a): Amerikai karmazsinbogyó (amerikai alkörmös) (Phytolacca americana L.). - In: CsIsZÁR Á. (szerk.), Inváziós növényfajok Magyarországon. Nyugat-magyarországi Egyetem Kiadó, Sopron, pp. 31-35.

BALOGH L. \& JuHÁsz M. (2012b): Kínai karmazsinbogyó (kínai alkörmös) (Phytolacca esculenta van Houtte). - In: CsIszÁR Á. (szerk.), Inváziós növényfajok Magyarországon. Nyugat-magyarországi Egyetem Kiadó, Sopron, pp. 37-41.

Barina Z., HARmos K. \& Schmotzer A. (2005): Orobanche cernua in Hungary. - Studia Botanica Hungarica 36: 5-11.

BARINA Z. \& KirÁly G. (2009): Cardamine L. - Kakukktorma [incl. Dentaria L. - Fogasír]. - In: KiRÁly G. (szerk.), Új magyar füvészkönyv. Magyarország hajtásos növényei. Határozókulcsok. Aggteleki Nemzeti Park Igazgatóság, Jósvafő, pp. 178-180.

Bartha D., Király G., Schmidt D., Tiborcz V., Barina Z., Csiky J., JakAB G., LeSku B., Schmotzer A., VidéKi R., Vojtкó A. \& ZóLYomi Sz. (szerk.) (2015): Magyarország edényes növényfajainak elterjedési atlasza. Nyugat-magyarországi Egyetem Kiadó, Sopron, 329 pp.

BölöNI J., KerTÉsz É., KeVEY B. \& ViróK V. (1998): A Fekete- és Fehér-Körös menti erdôk edényes növényfajainak listája és florisztikai értékelése. - Kutatási jelentés, mscr., Sopron, 26 pp.

BölÖNI J., KeRTÉsz É., KiRÁlY G. \& VIRóK V. (2000): A Fekete- és Fehér-Körös menti erdők botanikai értékei. - Kitaibelia 5 (1): 177-187.

BorbÁs V. (1881): Békésvármegye flórája. Értekezések a természettudományok köréből. XI. kötet. XVIII. szám. - A M. Tud. Akadémia Könyvkiadó-Hivatala, Budapest, 105 pp.

Boros Á. (1922): Adatok Békés- és Bihar-megyék síkjainak flórájához. - Magyar Botanikai Lapok 21: 32-33.

Boros Á. (1930): A páfrányok alföldi előfordulásához. - Botanikai Közlemények 27 (1-4): 77-78.

CsATHó A. I. (2009): A mezsgyék természetvédelmi jelentősége és védelmük időszerűsége. Természetvédelmi Közlemények 15: 171-181.

Deli T. (2012): Pocsolyalátonya. - In: JAKAB G. (szerk.), A Körös-Maros Nemzeti Park természeti értékei I. A Körös-Maros Nemzeti Park növényvilága. Körös-Maros Nemzeti Park Igazgatóság, Szarvas, pp. 96-97.

DövÉNYI Z. (szerk.) (2010): Magyarország kistájainak katasztere. Második, átdolgozott és bővített kiadás. - MTA Földrajztudományi Kutatóintézet, Budapest, 876 pp.

DRAGULEŞCU C. (1995): The flora and vegetation of the Mures (Maros) valley. - Tiscia monograph series 1: 47-111.

FARKAS S. (szerk.) (1999): Magyarország védett növényei. - Mezőgazda Kiadó, Budapest, 416 pp. 
HALÁSz Á. (1889): Makó város és környéke növényzete. - A Makói Államilag Segélyezett Községi Polg. Leányiskola Értesitője 9: 3-31.

HóDI L. (2012): Parlagi rézgyom (Iva xanthiifolia Nutt.). - In: CsıszÁR Á. (szerk.), Inváziós növényfajok Magyarországon. Nyugat-magyarországi Egyetem Kiadó, Sopron, pp. 243-247.

JAKAB G. (2005): Adatok a Dél-Tiszántúl flórájának ismeretéhez II. - Flora Pannonica 3: 91-119.

JАKAB G. (2012a): Örménygyökér. - In: JAKAB G. (szerk.), A Körös-Maros Nemzeti Park természeti értékei I. A Körös-Maros Nemzeti Park növényvilága. Körös-Maros Nemzeti Park Igazgatóság, Szarvas, pp. 112-113.

JAKAB G. (2012b): Kígyónyelv. - In: JAKAB G. (szerk.), A Körös-Maros Nemzeti Park természeti értékei I. A KörösMaros Nemzeti Park növényvilága. Körös-Maros Nemzeti Park Igazgatóság, Szarvas, pp. 170-171.

KERTÉSz É. (1989): A Dobozi ártéri ligeterdők florisztikai vizsgálata. - In: RÉTHY Zs. (szerk.), Dobozi Tanulmányok. Békés Megyei Múzeumok Igazgatósága, Békéscsaba, pp. 17-30.

KERTÉSz É. (1996): Adatok a Biharugrai Tájvédelmi Körzet flórájához (1986-1995). - Natura Bekesiensis 2: 37-64.

KERTÉsz É. (2000): Adatok a Dél-Tiszántúl flórájához. - A Békés Megyei Múzeumok Közleményei 21: 5-48.

KIRÁLY G. (szerk.) (2009a): Új magyar füvészkönyv. Magyarország hajtásos növényei. Határozókulcsok. Aggteleki Nemzeti Park Igazgatóság, Jósvafő, 615 pp.

KIRÁLY G. (2009b): Onagraceae - Ligetszépefélék családja. - In: KIRÁLY G. (szerk.), Új magyar füvészkönyv. Magyarország hajtásos növényei. Határozókulcsok. Aggteleki Nemzeti Park Igazgatóság, Jósvafő, pp. 297-301.

KIRÁlY G. (2009c): Scrophulariaceae (s. l.) - Tátogatófélék családja. - In: KIRÁLY G. (szerk.), Új magyar füvészkönyv. Magyarország hajtásos növényei. Határozókulcsok. Aggteleki Nemzeti Park Igazgatóság, Jósvafö, pp. 365-380.

KiRÁlY G. \& KiRÁLY A. (2005): Adatok és kiegészítések a magyar flóra ismeretéhez II. - Kitaibelia 10 (1): 88-103.

KoREN I. (1883): Szarvas virányának második javitott és bővitett felszámlálása. - Szarvasi Fögymnásium Évi Jelentése 1882/3-ról. pp. 3-54.

MÁTHÉ I. (1936): Növényszociológiai tanulmányok a körösvidéki liget- és szikes erdőkben. - Acta Geobotanica Hungarica 1 (1): 150-166.

Molnár Cs., Haszonits Gy., Malatinszky Á., Kovács G. K., Kovács G., Nagy T., MolnÁr V. A. \& TaKÁcs A. (2017): Pótlások Magyarország edényes növényfajainak elterjedési atlaszához III. - Kitaibelia 22 (1): 122-146.

MolnÁR V. A. (2011a): Fehér madársisak. - In: MolnáR V. A. (szerk.), Magyarország orchideáinak atlasza. Kossuth Kiadó, Budapest, pp. 200-201.

MolnÁR V. A. (2011b): Zöldes sarkvirág. - In: MolnÁR V. A. (szerk.), Magyarország orchideáinak atlasza. Kossuth Kiadó, Budapest, pp. 328-329.

NikLfELD H. (1971): Bericht über die Kartierung der Flora Mitteleuropas. - Taxon 20 (4): 545-571.

PApP V., KirÁly G., Koscsó J., Malatinszky Á., NAgY T., TAKÁcS A. \& Dima B. (2016): Taxonomical and chorological notes 2. - Studia botanica hungarica 47: 179-191.

PenKSZA K. \& KAPOCSI J. (1998): A Maros-völgy edényes növényei I. - Crisicum 1: 35-74.

PinKe Gy., BlazseK K., NAGY K., KARÁCSONY P. \& MAGYAR L. (2016): A magyarországi szójavetések gyomviszonyai. - Növényvédelem 52: 75-85.

PINTÉR I. (2009): Páfrányok osztálya - Pteridopsida. - In: KIRÁLY G. (szerk.), Új magyar füvészkönyv. Magyarország hajtásos növényei. Határozókulcsok. Aggteleki Nemzeti Park Igazgatóság, Jósvafő, pp. 75-86.

SALLAINÉ KAPOCSI J. (2012a): Ligeti csillagvirág. - In: JAKAB G. (szerk.), A Körös-Maros Nemzeti Park természeti értékei I. A Körös-Maros Nemzeti Park növényvilága. Körös-Maros Nemzeti Park Igazgatóság, Szarvas, pp. 174-175.

SAllainÉ KAPOCSI J. (2012b): Fehér madársisak. - In: JAKAB G. (szerk.), A Körös-Maros Nemzeti Park természeti értékei I. A Körös-Maros Nemzeti Park növényvilága. Körös-Maros Nemzeti Park Igazgatóság, Szarvas, pp. 178-179.

SAllainé Kapocsi J., JAKAB G., CSAThó A. I., Penksza K. \& Tóth T. (2012): A Dél-Tiszántúl növényfajainak Vörös Listája. - In: JакAв G. (szerk.), A Körös-Maros Nemzeti Park természeti értékei I. A Körös-Maros Nemzeti Park növényvilága. Körös-Maros Nemzeti Park Igazgatóság, Szarvas, pp. 382-389.

Schmotzer A. (2015): Ceratocephala testiculata (Crantz) Roth és további adatok a Bükkalja flórájához. Kitaibelia 20 (1): 81-142.

SchmidT D. \& LENGYEL A. (2008): Adatok a Pannonhalmi-dombság flórájának ismeretéhez. - Flora Pannonica 6: 25-57. 
SimonKAI L. (1881): Nagyvárad és a Sebes-Körös felsőbb vidéke. - Mathematikai és Természettudományi Közlemények 16: 71-150.

Soó R. (1929): Revision der Orchideen Südosteuropas und Südwestasiens. - Botanisches Archiv 23: 1-196.

Soó R. (1966): A magyar flóra és vegetáció rendszertani-növényföldrajzi kézikönyve II. - Akadémiai Kiadó, Budapest, 655 pp.

Soó R. (1970): A magyar flóra és vegetáció rendszertani-növényföldrajzi kézikönyve III. - Akadémiai Kiadó, Budapest, 506 pp.

Soó R. (1980): A magyar flóra és vegetáció rendszertani-növényföldrajzi kézikönyve VI. - Akadémiai Kiadó, Budapest, 556 pp.

Soó R. \& JÁvoRKA S. (1951): A magyar növényvilág kézikönyve I. - Akadémiai Kiadó, Budapest, 582 pp.

Soó R. \& MÁTHÉ I. (1938): A Tiszántúl flórája. Flora Planitiei Hungariae Transtibiscensis. Magyar Flóramüvek II. - Editio Instituti Botanici Universitatis Debreceniensis, Debrecen, 192 pp.

SzujKó-Lacza J. \& Kováts D. (szerk.) (1993): The flora of the Kiskunság National Park I. - Magyar Természettudományi Múzeum, Budapest, 465 pp.

TAKÁCS A., SCHMOTZER A. \& SULYOK J. (2013): Florisztikai adatok a Sajó-Hernád-sík területéről. - Kitaibelia 18 (1-2): 73-88.

TAKÁcs A., ZÁKÁNy A., GulYás G., Koscsó J. \& SRAmkó G. (2014): Florisztikai adatok a Tiszántúl északi pereméről. - Kitaibelia 19 (2): 275-294.

Takács A., Nagy T., SRamkó G., Lovas-Kiss Á., SÜveges K., Lukács B. A., Fekete R., LÖKi V., Malatinszky Á., E. Vojtkó A., Koscsó J., Pfliegler W. P., Nótári K. \& Molnár V. A. (2016): Pótlások a Magyarország edényes növényfajainak elterjedési atlaszához I. - Kitaibelia 21 (1): 101-115.

Tóтн M. (1967): A Maros hullámterének fitocönológiai jellemzése. - Doktori értekezés, Makó, 116 pp.

ZólYomi B. (1945-1946): Természetes növénytakaró a Tiszafüredi öntözőrendszer területén. Öntözésügyi Közlemények 7-8 (1-2): 62-75.

Beérkezett: 2017. 10.11. • Elfogadva: 2017.11. 09. 